(C) 2014

Горальська І. Ю., кандидат ветеринарних наук

Житомирський національний агроекологічний університет

\title{
ДІАГНОСТИКА ТА ЛІКУВАННЯ ГЕПАТОПАТІЇ У СОБАК ЗА БАБЕЗІОЗУ
}

\section{Рецензент - кандидат ветеринарних наук О. В. Кручиненко}

У собак, хворих на бабезіоз, за різних стадій хвороби встановлено патологію печінки (гепатопатію), щуо характеризується болючістю в діляниі печінкового поля, гепатомегалією, іктеричністю кон'юнктиви, гіпоальбумінемією, гіпербілірубінемією, збільшенням активності АлАТ, АсАТ та ГГТП. Тритижневий курс лікування собак за бабезіозу з ознаками жовтяниці із застосуванням глюкози, аскорбінової кислоти, глутаргіну, контрикалу, катозалу, панангіну, лазиксу та есениіале форте забезпечує поступове, неповне відновлення функиіонального стану печінки.

Ключові слова: собаки, бабезіоз, хвороба, жовтяниия, білірубін, печінка.

Постановка проблеми. 3 розвитком можливостей діагностики хвороб внутрішніх органів виявлено, що хвороби печінки (гепатопатіi) зустрічаються значно частіше, ніж було раніше. У зв'язку з важливістю та багатогранністю функцій печінка наділена природною здатністю до високої регенерації, тому виникнення патологічних процесів під дією різних факторів у печінці стають помітними й проявляються клінічно лише в прогресуючих стадіях хвороби $[1,2]$.

Аналіз основних досліджень і публікацій, у яких започатковано розв'язання проблеми. Гепатопатія - це зниження однієї або декількох функцій печінки, токсично-запальні дегенеративні пошкодження клітин паренхіми печінки. Розрізняють гостру та хронічну печінкову недостатність. За гострої недостатності спостерігаються масивні пошкодження паренхіми печінки, що розвиваються впродовж короткого часу. В основі лежить дифузна жирова дистрофія та некроз гепатоцитів. Знижуються всі функції печінки, утворюються багаточисельні коллатералі між ворітною веною, внаслідок чого токсичні продукти минають печінку. Відбувається тяжке самоотруєння, передусім продуктами розпаду білка - азотистими речовинами - аміаком. Виникає гіпокаліємія, гіпонатріємія, метаболічний ацидоз [2, 3].

Легкі форми гепатопатій перебігають безсимптомно, проте за більш тривалого перебігу в патологію включаються нирки, серце, селезінка, підшлункова залоза, кишечник.

На тяжке ураження печінки безпомилково вказує жовтяниця та деякі інші основні синдроми гепатопатій: анорексія, блювота; анемія; синдром портальної гіпертензії; гепатолієнальний синдром та ін.

Ступінь ураження паренхіми печінки залежить від характеру фактора, що пошкоджує, тривалості дії та індивідуальної чутливості. Одним із таких факторів є гемоліз еритроцитів, що розвивається за бабезіозу у собак. Продукти життєдіяльності Babesia canis, накопичуючись в еритроцитах, спричинюють порушення функцій крові, нервової та серцево-судинної систем, шлунково-кишкового тракту, печінки, нирок тощо [3].

Незважаючи на значні компенсаторні можливості печінки, гострий перебіг бабезіозу у собак супроводжується пошкодженням їі паренхіми. Ураження печінки - один із найхарактерніших синдромів цього захворювання. Наслідком розвитку гемолітичної анемії є жовтяниця, що вказує на порушення обміну або виділення жовчних пігментів [4-6].

Зазвичай бабезіоз у собак розвивається досить стрімко, а його наслідки тривалий час доводиться усувати. Для повноцінного лікування такого роду ускладнень, які нерідко перебігають безсимптомно, необхідна досконала діагностика патології печінки.

Мета досліджень: обгрунтування інформативності ранніх діагностичних показників функціонального стану печінки, що розвивається у собак, хворих на бабезіоз; з'ясування патогенетичних ланок їх розвитку та дослідження показників пігментного обміну, зокрема білірубіну та його фракцій.

Матеріали і методи досліджень. Роботу виконували на базі кафедри внутрішніх хвороб тварин та фізіологіі, а також навчально-ветеринарної клініки патології тварин Житомирського національного агроекологічного університету.

Об'єктом для дослідження були собаки порід німецька і середньоазійська вівчарки та ротвейлери віком від 18 місяців до 8 років - клінічно здорові та спонтанно хворі на різних стадіях прояву патології печінки і нирок за бабезіозу.

Для проведення експериментальних дослі- 


\section{ВЕТЕРИНАРНА МЕДИЦИНА}

джень були сформовані чотири групи собак: перша $(\mathrm{n}=16)$ - із клінічними ознаками та симптомами гострого перебігу бабезіозу у перші дві доби прояву (перша стадія); друга (n=13) - на 34-y добу (друга стадія); третя $(\mathrm{n}=16)$ - на 5-6-y добу (третя стадія); четверта $(\mathrm{n}=20)$ - клінічно здорові.

Дослідження функціонального стану печінки проводили за показниками білкового, вуглеводного, пігментного і ліпідного обмінів та активності індикаторних ферментів. Білоксинтезувальну функцію печінки визначали за рівнем у сироватці крові загального білка (рефрактометрично), його фракцій (нефелометрично) та тимоловою коагуляційною пробою; пігментну - за вмістом загального і кон'югованого білірубіну методом Ієндрашека і Грофа; сечовиноутворювальну - за рівнем сечовини (колірною реакцією 3 діацетилмонооксимом); вуглеводну - за вмістом у сироватці крові глюкози (глюкозооксидазним методом); ліпідну - за рівнем холестеролу (за Ільком). Стан гепатоцитів оцінювали за активністю індикаторних для печінки ферментів у сироватці крові: аланінової (АлАТ) та аспарагінової (АсАТ) амінотрансфераз (кінетичним методом Райтмана-Френкеля); гаммаглутамілтранспептидази (ГГТП) - кінетичною реакцією $3 \alpha-\gamma$ глутаміл-4-нітроаланіном; лужної фосфатази (ЛФ) - кінетичною реакцією за утворенням п-нітрофенолу.

Результати досліджень. За гепатопатії у $100 \%$ хворих виявляли болючість у ділянці печінкового поля та ознаки гепатомегалії. Дослідження показників пігментного обміну, а саме білірубіну та його фракцій, були найбільш показовими. Загальна кількість білірубіну за бабезіозу була вірогідно збільшеною вже 3 перших днів прояву хвороби. За норми у собак 0,6-4,5 мкмоль/л та у дослідних тварин контрольної групи 2,7士0,21 мкмоль/л; перша стадія захворювання супроводжувалася збільшенням цього кров'яного пігменту до $11,8 \pm 0,39$ мкмоль/л (у 4,4 разу), друга - до $22,6 \pm 0,99$ (8,4 разу) й третя - до $45,9 \pm 3,26$ мкмоль/л (у 17 разів).

За посиленого розпаду гемоглобіну утворювалася значна кількість некон'югованого (непроведеного) білірубіну, нерозчинного у воді, - не спроможного проникати через нирковий бар'єр i токсичного для головного мозку. За першої стадії хвороби його вміст у середньому становив $10,7 \pm 0,46$ мкмоль/л, другої - $14,8 \pm 1,17$ і третьої $32,4 \pm 1,91$ мкмоль/л, що свідчить про розвиток гемолітичної жовтяниці.

Частка кон'югованого (зв'язаного) білірубіну збільшувалася поступово: на початку захворю- вання рівень пігменту становив $1,0 \pm 0,13$ мкмоль/л. Надалі кількість холебілірубіну у сироватці крові була значною: за другої стадії вона становила 7,8 $\pm 0,96$ (4,3-16,3 мкмоль/л) і третьої

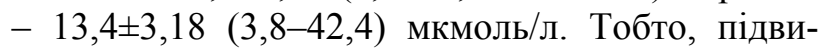
щення кон'югованого білірубіну у сироватці крові вказує на розвиток паренхіматозної жовтяниці, що $€$ свідченням деструктивно-дистрофічних змін у паренхімі печінки.

У ході дослідження білоксинтезувальної функції печінки гіпопротеїнемію виявляли у 7,7\% собак за другої стадії хвороби та у $39,4 \%$ - за третьої. Суттєве зниження кількості альбумінів у $100 \%$ хворих спостерігали за другої та третьої стадій $(38,4 \pm 0,39$ та $34,3 \pm 0,29 \%$; $<<0,001)$ внаслідок патології печінки й нирок. Збільшення у сироватці крові глобулінів відбувалося за рахунок $\beta$ - та $\gamma$-фракцій. Отже, у хворих собак виникає диспротеїнемія, що характеризується зниженням альбуміно-глобулінового коефіцієнта $(\mathrm{p}<0,001)$ й позитивними результатами тимолової проби $(\mathrm{p}<0,001)$.

За другої і третьої стадій бабезіоз, відповідно, у 46 і $94 \%$ хворих встановили холестеролемію $(6,7 \pm 0,11$ та $8,1 \pm 0,30$ ммоль/л), спричинену, ймовірно, високою активністю $\beta$-окси- $\beta$-метилглутарил-Ко-А-редуктази.

На всіх стадіях перебігу патологічного процесу встановили збільшення кількості загального білірубіну за рахунок обох фракцій. Рівень некон'югованого білірубіну становив $10,7 \pm 0,46$; $14,8 \pm 1,17$ та $32,4 \pm 1,91$ мкмоль/л відповідно по стадіях хвороби, що вказує на розвиток гемолітичної жовтяниці. За другої та третьої стадій зростає вміст кон'югованого білірубіну $(7,8 \pm 0,96$ та $13,4 \pm 3,18$ мкмоль/л), що є типовим для дистрофічних змін паренхіми печінки та паренхіматозної жовтяниці.

На ураження клітинних структур печінки вказує й висока активність АсАТ і АлАТ. За другої та третьої стадій хвороби збільшення активності АлАТ встановлено у $100 \%$ тварин $(80,4 \pm 4,53$ і $103,9 \pm 7,44$ Од/л), що у 2,5 та 3,2 рази більше за максимальну норму (55 Од/л). Підвищеною у хворих тварин була й активність АсАТ: за другої стадії у 2,4 разу, третьої - 5,7 порівняно з клінічно здоровими $(\mathrm{p}<0,001)$. У ці періоди захворювання зростала елімінація в кров лужної фосфатази $(154,9 \pm 13,14$ і 194,7士17,06 Од/л відповідно). У хворих собак розвивається внутрішньопечінковий холестаз, який підтверджується збільшен-

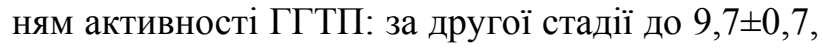

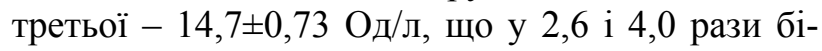
льше, ніж у клінічно здорових ( $<<0,001)$.

Таким чином, ураження печінки за бабезіозу 


\section{ВЕТЕРИНАРНА МЕДИЦИНА}

проявляється синдромами: цитолітичним - гіпертермія, гіперферментемія АлАТ, АсАТ; мезенхімально-запальним - гепатомегалія, гіперглобулінемія; холестатичним - гіперферментемія ГГТП та ЛФ та гепато-целюлярної недостатності - гіпербілірубінемія, гіпоальбумінемія.

Для лікування собак з ознаками жовтяниці за гострого перебігу бабезіозу застосовували схему комплексної патогенетичної терапії: глутаргін (внутрішньовенно крапельно 2 мл на 0,9 \% розчині $\mathrm{NaCl}$ двічі в день - 10 днів); контрикал (внутрішньовенно крапельно 20 тис. АТрО на 100 мл 0,9\% розчину $\mathrm{NaCl}$ один раз на добу впродовж семи днів); панангін (внутрішньовенно крапельно в 100 мл 0,9\% розчину $\mathrm{NaCl}$ ); катозал (2 мл підшкірно 1 раз на добу - 14 днів); $5 \%$ розчин глюкози (100 мл) з аскорбіновою кислотою (2-5 мг/кг) внутрішньовенно крапельно двічі на день -7 днів. Лазикс у дозі 1 мл двічі на добу внутрішньовенно впродовж семи днів та гепатопротектор - есенціале форте - 1 мл/10 кг маси тіла внутрішньовенно, 5 днів, а потім із 8-го по 21-й день перорально - по капсулі двічі на добу.

Після лікування у тварин спостерігали відновлення апетиту, зникала болючість у ділянці печінки, кон'юнктива на 21-й день набувала блідорожевого кольору. Білок- і білірубіносинтезувальна функції гепатоцитів у собак відновлюються не повністю, на що вказує гіпоальбумінемія (37,9\% від загального білка) та підвищений уміст загального i кон'югованого білірубіну

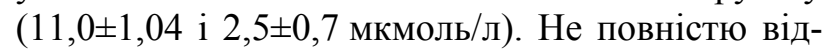

\section{БІБЛІОГРАФІЯ}

1. Зилва Дж. Ф. Клиническая химия в диагностике и лечении / Дж. Ф. Зилва, П. Р. Пэннел: [пер. с англ.]. - М. : Медицина, 1988. - 528 с.

2. Клиническая лабораторная диагностика в ветеринарии / [И. П. Кондрахин, Н. В. Курилов, А. Г. Малахов [и др.]. - М. : Агропромиздат, 1985. -287 c.

3. Клиническая оценка биохимических показателей при заболеваниях внутренних органов / под ред. В. Г. Перерия, Ю. В. Хмелевского. - К. : Здоровье, 1993. - 190 с. бувається відновлення структури гепатоцитів, оскільки активність АсАТ була у 2,5 разу вищою, ніж у здорових. Тритижневий курс лікування спричинює поступову регенерацію ендотелію жовчних шляхів, про що свідчить зменшення активності ГГТП і ЛФ. Однак у частини собак (27,3 і 18,2 \%) вона не відновлювалася.

Отже, за розвитку жовтяниці навіть інтенсивний курс терапії впродовж 21-го дня не забезпечує повного відновлення функціонального стану печінки, тому реабілітація тварин за такого перебігу патології повинна бути продовжена.

\section{Висновки:}

1. За бабезіозу розвивається змішана - гемолітично-паренхіматозна жовтяниця 3 ознакою холестазу. Тяжкість захворювання визначається наявністю та інтенсивністю жовтяниці. Найбільш інформативним показником ранніх стадій розвитку патології печінки є гіперферментемія; про більш тяжкий ступінь ураження гепатоцитів свідчать гіпо- і диспротеїнемія.

2. Тритижневий курс лікування собак за бабезіозу 3 ознаками жовтяниці із застосуванням глюкози, аскорбінової кислоти, глутаргіну, контрикалу, катозалу, панангіну, лазиксу та есенціале форте забезпечує поступове відновлення функціонального стану печінки. Однак повного відновлення навіть на 21-у добу від початку лікування не було, про що свідчать гіпоальбумінемія

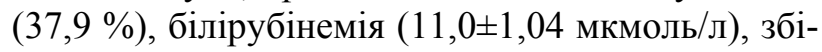
льшена активність АсАТ і ГГТП.

4. Методологические основы оценки клиникоморфологических показателей крови домашних животных / Бажибина Е., Коробов А. [и др.]. М. : Аквариум, 2005. - 128 с.

5. Мейер Д. Ветеринарная лабораторная медицина. Интерпретация и диагностика / Мейер Д., Харви Дж.; [пер. с англ.]. - М. : Софион, 2007. $456 \mathrm{c}$.

6. Фасоля В. П. Диспансеризація собак службових порід: автореф. дис. ... доктора вет. наук: спец. 16.00.01 / В. П. Фасоля. - Біла Церква, 2008. -38 c. 